\title{
The influence of potassium and calcium ions on nitrogen metabolism of cucumber seedlings
}

\author{
GENOWEFA KUBIK-DOBOSZ \\ Department of Plant Physiology, Institute of Botany, Wroclaw University, \\ Kanonia 6/8, 50-328 Wrocław, Poland
}

(Received: December 14, 1979)

Abstract

It was found that $\mathrm{K}^{+}$or $\mathrm{Ca}^{2+}$ deficiency in a nitrate or ammonium medium increased the amount of accumulated tatal and non-protein nitrogen in some organs of cucumber seedlings, as also caused changes in accumulated potassium and calcium. Lack of $\mathrm{K}^{+}$or $\mathrm{Ca}^{2+}$ in a medium which did not contain nitrogen led to an increased level of glutamate dehydrogenase, alanine aminotransferase and aspartate aminotransferase activity in the cotyledons and roots of cucumbers. Similar changes in the activity of these enzymes were noted in certain organs of seedlings growing in nitrate or ammonium medium with decreased $\mathrm{K}^{+}$or $\mathrm{Ca}^{2+}$ contents, although the magnitude of these changes depended upon the applied dosage of these cations, the form of mineral nitrogen, developmental phase of plants and the plant organ dealt with.

\section{INTRODUCTION}

Potassium is known as a activator of numerous enzymatic reactions (Evans and Sorger 1966), as also as an important factor regulating the nitrogen system in plants (F i a lová and P i chl 1973, M e ngel and Simic 1973). Accumulation of free amino acids and amides has been noted in plants developing at a lowered availability of potassium (Ts o and Murtrey 1960). Vyskrebentseva (1963) showed that potassium deficiency in the medium results in a considerable increase of alanine and aspartic acid content in pumpkin seedlings. An increased accumulation of free amino acids in plant tissue was likewise observed in cases of calcium insufficiency, although the effect noted depended upon the developmental phase of the plant and the organ under observation ( $\mathrm{Pal}$ and Laloraya 1973).

Normal functioning of the enzymatic reduction of nitrates depends upon the presence of potassium and calcium ions ( $\mathrm{P}$ a u ls e $\mathrm{n}$ and $\mathrm{H}$ a r- 
per 1968, Buczek 1979). The part played by these ions in the regulation of the activity of other enzymes connected with nitrogen assimilation requires further studies.

The present study was aimed at finding the sources of changes in the content of nitrogen components in plants showing symptoms of potassium or calcium deficiency.

\section{MATERIAL AND METHODS}

The experiments were conducted on cucumber seedlings (Cucumis sativus L. of the "Monastyrski" variety). Nitrate and ammonium medium containing $200 \mathrm{mg}$ of $\mathrm{N}$ per $\mathrm{dm}^{3}$ were used $(\mathrm{Kubik}-\mathrm{Dobosz}$ and Soroka 1979). Potassium content in a complete nitrate or amonium medium corresponded to $150 \mathrm{mg} / \mathrm{dm}^{3}$, of calcium $-18 \mathrm{mg} / \mathrm{dm}^{3}$. Nitrate or ammonium media containing ten told lower amounts of $\mathrm{K}^{+}$ and $\mathrm{Ca}^{2+}$, as also media not containing potassium or calcium ions were used in this experiments too. Phosphate ions eliminated together with $\mathrm{K}^{+}$ions were introduced in the form of $\mathrm{NaH}_{2} \mathrm{PO}_{4}$. After four days the plants were divided by separating cotyledons, hypocotyls and roots, and after 13 days by separating the leaves, stems (without cotyledons) and roots. Total and non-protein nitrogen was next determined in the various organs of the cucumber seedlings, as also potassium and calcium content, glutamate dehydrogenase, alanine aminotransferase, and aspartate aminotransferase activity.

Non-protein nitrogen was determined after extracting the dried plant matter with hot water and removing soluble proteins with cadmium hydroxide (B rzeski and Kani u a 1956). Non-protein and total nitrogen contents were determined by means of Kjeldahl's micromethod (Mejbaum-Katzenellenbogen and Mochnacka 1969).

Analyses of potassium and calcium contents were carried out by digesting samples in concentrated nitric acid and $30 \%$ hydrogen peroxide, followed by determining potassium and calcium in a flame photometer using a $\mathrm{K} 77 \mathrm{~J}$ and $\mathrm{Ca} 63 \mathrm{~J}$ filter.

Glutamate dehydrogenase (GDH) was extracted according to $\mathrm{H}$ a rper and Pa ulsen (1969), alanine aminotransferase (GPT) and aspartate aminotransferase (GOT) according to $\mathrm{Hedley}$ and $\mathrm{Stoddart}$ (1971). GDH activity was measured according to $\mathrm{Pahlich}$ and $\mathrm{Joy}$ (1971) and expressed in nmoles of oxidized NADH per minute per gram of fresh mass. GPT and GOT activity was determined according to Hedley and Stoddart (1971) and presented in umoles of product per minute per gram of fresh mass. Results consisted of the average from three repetitions. 
Abbreviations used. GDH - glutamate dehydrogenase, GPT - alanine aminotransferase, GOT - aspartate aminotransferase.

\section{RESULTS}

Decreasing the dosage of $\mathrm{K}^{+}$in the ammonium medium was linked with an increase in the total and non-protein nitrogen contents in all of the analysed seedling fragments (Table 1), reacting at times even as high as $50 \%$. However, differences were less distinct and referred only to some cucumber organs in the case of seedlings growing in nitrate medium with lowered $\mathrm{K}^{+}$content. A lowered availability of potassium likewise reacted upon accumulation of calcium in seedlings, however the differences obtained were not univocal and depended upon the source of mineral nitrogen and upon the plant organ under investigation. Accumulation of larger amount of calcium was observed in some cases, and a distinct decline in the content of this component in other (Table 1).

In general no increased accumulation of specific nitrogen fractions was observed in the cotyledons, leaves and roots of seedlings growing for four days in an ammonium medium with a lowered dosage of calcium or its total lack (Table 2). However, a distinct increase in the non-protein nitrogen content in the leaves stems, and roots of seedlings growing in an ammonium medium with a ten-fold lower dosage of calcium was noted after 13 days of development. Similar changes were obtained for the leaves and stems of plants assimilating $\mathrm{NO}_{3}^{-}$ions at a decreased availability of calcium. Data collected in Table 2 furthermore show that irrespective of the form of nitrogen applied, all of the analysed organs of plants deficient of calcium - with the exception of the leaves of seedlings growing on a nitrate medium - accumulated considerably less potassium than the control plants.

Table 3 presents the results concerning the effect of various $\mathrm{K}^{+}$ion concentration on GDH, GPT and GOT activity in cucumber seedlings after 4 and 13 days of growth in media containing nitrate or ammonium forms of nitrogen. It was found that total lack of $\mathrm{K}^{+}$in an ammonium medium resulted in an increase of $40 \%$ of $\mathrm{GDH}$ activity in cotyledons. A distinct increase of GDH activity was likewise observed in the leaves of seedlings growing in a nitrate medium with a ten-fold decreased dosage of potassium ions. Changes in GDH activity in other organs of cucumber seedlings were less contrasting.

GPT activity in the cotyledons of seedlings growing in a nitrate or ammonium medium reacted a maximal level at total lack of potassium in the medium (Table 3). The change in GPT activity in four day old cucumber roots was less distinct. Development of seedlings over a longer time in the nitrate or ammonium medium with a lowered content of $\mathrm{K}^{+}$ions led to a decrease of GPT activity in the roots and an increased 
Table 1

Content of total nitrogen $(\mathrm{N}-\mathrm{t})$, non-protein nitrogen $(\mathrm{N}-\mathrm{n})$, potassium, and calcium in mg per gram of dry mass in cucumbers growing 4 days (A) and 13 days (B) in a nitrate or ammonium medium with various potassium contents

\begin{tabular}{|c|c|c|c|c|c|c|c|c|c|c|c|c|c|}
\hline Source of nitrogen & $\begin{array}{l}\text { Potassium concent ration } \\
\qquad(\mathrm{mg})\end{array}$ & $\mathrm{N}-\mathrm{t}$ & $\mathrm{N}-\mathrm{n}$ & K & $\mathrm{Ca}$ & $N-t$ & $N-n$ & K & $\mathrm{Ca}$ & $N-t$ & $N-n$ & $\mathrm{~K}$ & $\mathrm{Ca}$ \\
\hline \multicolumn{2}{|l|}{ A } & \multicolumn{4}{|c|}{ cotyledons } & \multicolumn{4}{|c|}{ hypocotyls } & \multicolumn{4}{|c|}{ roots } \\
\hline \multirow{3}{*}{$\mathrm{NO}_{3}^{-}$} & 150 & 70.0 & 17.7 & 37.4 & 4.8 & 58.8 & 13.1 & 52.6 & 4.4 & 47.6 & 6.3 & 46.3 & 3.7 \\
\hline & 15 & 72.1 & 21.0 & 22.2 & 6.0 & 62.3 & 13.2 & 43.6 & 4.4 & 49.7 & 7.7 & 27.8 & 3.2 \\
\hline & 0 & 77.0 & 15.4 & 6.4 & 5.6 & 63.0 & 12.6 & 10.0 & 7.0 & 52.5 & 8.4 & 7.2 & 2.7 \\
\hline \multirow[t]{3}{*}{$\mathrm{NH}_{4}^{+}$} & 150 & 74.9 & 28.5 & 41.4 & 2.8 & 65.8 & 39.2 & 50.0 & 3.3 & 45.5 & 14.7 & 51.3 & 2.7 \\
\hline & 15 & 79.1 & 34.5 & 25.5 & 3.0 & 65.8 & 40.1 & 27.4 & 3.4 & 48.3 & 16.8 & 26.0 & 3.3 \\
\hline & 0 & 84.0 & 36.9 & 6.8 & 1.7 & 70.0 & 40.1 & 5.0 & 3.2 & 48.3 & 19.6 & 8.3 & 3.5 \\
\hline \multicolumn{2}{|l|}{$\mathrm{B}$} & \multicolumn{4}{|c|}{ leaves } & \multicolumn{4}{|c|}{ stems } & \multicolumn{4}{|c|}{ roots } \\
\hline \multirow[t]{2}{*}{$\mathrm{NO}_{3}^{-}$} & 150 & 62.3 & 9.8 & 51.2 & 10.0 & 38.5 & 3.3 & 59.0 & 6.5 & 44.1 & 5.6 & 27.0 & 3.5 \\
\hline & 15 & 67.2 & 9.3 & 28.6 & 14.2 & 37.8 & 6.5 & 26.8 & 7.2 & 42.0 & 5.6 & 6.3 & 3.5 \\
\hline \multirow[t]{2}{*}{$\mathrm{NH}_{4}^{+}$} & 150 & 74.9 & 18.2 & 45.0 & 2.8 & 60.6 & 39.2 & 48.2 & 4.4 & 43.4 & 10.3 & 42.8 & 2.7 \\
\hline & 15 & 81.2 & 22.8 & 30.6 & 4.2 & 70.7 & 43.4 & 23.6 & 4.4 & 49.7 & 15.4 & 34.3 & 4.0 \\
\hline
\end{tabular}


Table 2

Content of total nitrogen $(\mathrm{N}-\mathrm{t})$, non-protein nitrogen $(\mathrm{N}-\mathrm{n})$, potassium, and calcium in $\mathrm{mg}$ per gram of dry mass in cucumbers growing 4 days (A) and 13 days (B) in a nitrate or ammonium

medium with various calcium contents

\begin{tabular}{|c|c|c|c|c|c|c|c|c|c|c|c|c|c|}
\hline Source of nitrogen & $\begin{array}{l}\text { Calcium concentration } \\
\qquad(\mathrm{mg})\end{array}$ & $N-t$ & $N-n$ & $\mathrm{~K}$ & $\mathrm{Ca}$ & $\mathrm{N}-\mathrm{t}$ & $\mathrm{N}-\mathrm{n}$ & $\mathrm{K}$ & $\mathrm{Ca}$ & $\mathrm{N}-\mathrm{t}$ & $N-n$ & $\mathrm{~K}$ & $\mathrm{Ca}$ \\
\hline \multicolumn{2}{|l|}{ A } & \multicolumn{4}{|c|}{ cotyledons } & \multicolumn{4}{|c|}{ hypocotyls } & \multicolumn{4}{|c|}{ roots } \\
\hline \multirow[t]{3}{*}{$\mathrm{NO}_{3}^{-}$} & 18.0 & 70.0 & 17.7 & 37.4 & 4.8 & 58.8 & 13.1 & 52.6 & 4.4 & 47.6 & 6.3 & 46.3 & 3.7 \\
\hline & 1.8 & 70.0 & 18.7 & 32.0 & 1.3 & 56.7 & 13.1 & 47.0 & 0.98 & 50.4 & 7.7 & 36.2 & 1.8 \\
\hline & 0 & 72.1 & 15.9 & 23.6 & 0.54 & 58.8 & 17.3 & 26.0 & 0.54 & 44.1 & 8.4 & 20.0 & 0.67 \\
\hline \multirow[t]{3}{*}{$\mathrm{NH}_{4}^{+}$} & 18.0 & 74.9 & 28.5 & 41.4 & 2.8 & 65.8 & 39.2 & 50.0 & 3.3 & 45.5 & 14.7 & 51.3 & 2.7 \\
\hline & 1.8 & 79.8 & 33.6 & 25.0 & 1.4 & 64.4 & 34.5 & 32.0 & 1.3 & 44.1 & 13.3 & 34.0 & 1.6 \\
\hline & 0 & 79.8 & 34.5 & 23.0 & 0.98 & 68.6 & 37.8 & 36.0 & 0.7 & 46.2 & 12.6 & 29.5 & 1.2 \\
\hline \multicolumn{2}{|l|}{ B } & \multicolumn{4}{|c|}{ leaves } & \multicolumn{4}{|c|}{ stems } & \multicolumn{4}{|c|}{ roots } \\
\hline \multirow[t]{2}{*}{$\mathrm{NO}_{3}^{-}$} & 18.0 & 62.3 & 9.8 & 51.2 & 10.0 & 38.5 & 3.3 & 59.0 & 6.5 & 44.1 & 5.6 & 27.0 & 3.5 \\
\hline & 1.8 & 66.5 & 13.1 & 50.0 & 1.8 & 41.3 & 5.6 & 42.8 & 1.8 & 35.7 & 4.2 & 10.8 & 2.3 \\
\hline \multirow[t]{2}{*}{$\mathrm{NH}_{4}^{+}$} & 18.0 & 74.9 & 18.2 & 45.0 & 2.8 & 60.6 & 39.2 & 48.2 & 4.4 & 43.4 & 10.3 & 42.8 & 2.7 \\
\hline & 1.8 & 85.4 & 30.8 & 41.2 & 1.4 & 70.0 & 47.0 & 37.8 & 1.7 & 42.0 & 15.9 & 32.8 & 2.1 \\
\hline
\end{tabular}


Table 3

GDH, GPT, and GOT activity after 4 days (A) and 13 days (B) of growth of cucumber seedlings in a nitrate or ammonium medium with various potassium contents

\begin{tabular}{|c|c|c|c|c|c|c|c|}
\hline $\begin{array}{c}\text { Source of } \\
\text { nitrogen }\end{array}$ & $\begin{array}{c}\text { Potassium } \\
\text { concentration } \\
(\mathrm{mg})\end{array}$ & \multicolumn{2}{|c|}{$\begin{array}{c}\text { GDH } \\
\text { nmoles oxid. } \\
\text { NADH min } \text { min }^{-1} \mathrm{~g}^{-1} \\
\text { fr. wt. }\end{array}$} & \multicolumn{2}{|c|}{$\begin{array}{c}\text { GPT } \\
\mu \text { moles prod. } \\
\mathrm{min}^{-1} \mathrm{~g}^{-1} \text { fr. wt. }\end{array}$} & \multicolumn{2}{|c|}{$\begin{array}{c}\text { GOT } \\
\mu \text { moles prod. } \\
\min ^{-1} \mathrm{~g}^{-1} \text { fr. wt. }\end{array}$} \\
\hline \multicolumn{2}{|l|}{ A } & cotyledons & roots & cotyledons & roots & cotyledons & roots \\
\hline \multirow[t]{3}{*}{$\mathrm{NO}_{3}^{-}$} & 150 & 163 & 300 & 2.55 & 0.53 & 2.22 & 0.23 \\
\hline & 15 & 183 & 358 & 2.95 & 0.55 & 2.35 & 0.33 \\
\hline & 0 & 146 & 367 & 3.30 & 0.67 & 2.42 & 0.57 \\
\hline \multirow[t]{3}{*}{$\mathrm{NH}_{4}^{+}$} & 150 & 462 & 1244 & 2.80 & 0.92 & 2.03 & 0.60 \\
\hline & 15 & 479 & 1240 & 4.00 & 0.96 & 2.35 & 0.74 \\
\hline & 0 & 650 & 1263 & 4.35 & 0.96 & 2.48 & 0.77 \\
\hline \multicolumn{2}{|l|}{ B } & leaves & roots & leaves & roots & leaves & roots \\
\hline \multirow{4}{*}{$\begin{array}{l}\mathrm{NO}_{3}^{-} \\
\mathrm{NH}_{4}^{+}\end{array}$} & 150 & 450 & 320 & 2.97 & 0.42 & 1.78 & 0.45 \\
\hline & 15 & 725 & 392 & 2.85 & 0.28 & 1.95 & 0.30 \\
\hline & 150 & 1091 & 1262 & 4.50 & 1.34 & 2.08 & 0.77 \\
\hline & 15 & 1283 & 1281 & 6.96 & 1.08 & 2.45 & 0.90 \\
\hline
\end{tabular}

activity of this enzyme in the leaves of plants assimilating ammonium ions. A drop in $\mathrm{K}^{+}$content in the medium likewise led to an increase in GOT activity in the roots of seedlings after four days of growth in a nitrate or ammonia medium, although after 13 days of growth on an ammonia medium a lowered GOT activity was noted in the roots of seedlings, resulting from a lower availability of $\mathrm{K}^{+}$ions.

As can be seen from Table 4 the lack of $\mathrm{Ca}^{2+}$ ions in a nitrate or ammonium medium resulted in an increased GDH activity in the cotyledons of seedlings after four days of growth, at a lack of similar changes in the roots. However, after 13 days of growth, GDH activity in the roots of seedlings in the ammonium medium with a ten-fold lower content of $\mathrm{Ca}^{2+}$ was higher than in the control plants. GPT activity increased in the cotyledons of seedlings growing in a nitrate or ammonium medium with $\mathrm{Ca}^{2+}$ deficiency with greatest changes taking place in GPT activity in the mentioned plant organs at total lack of $\mathrm{Ca}^{2+}$. The lack or deficiency of calcium ions in the ammonium medium also caused an increase in GPT and GOT activity in the roots of 4- and 13-day old seedlings.

The experiments showed that the form of mineral nitrogen does affect changes in the activity of the enzymes under investigation in linkage with the use of various doses of $\mathrm{K}^{+}$or $\mathrm{Ca}^{2+}$. Hence, the following experiment consisted of investigating GDH, GPT and GOT activities in seedlings growing in a medium lacking nitrogen (-N), 
Table 4

GDH, GPT, and GOT activity after 4 days (A) and 13 days (B) of growth of cucumber seedlings in a nitrate or ammonium medium with various calcium contents

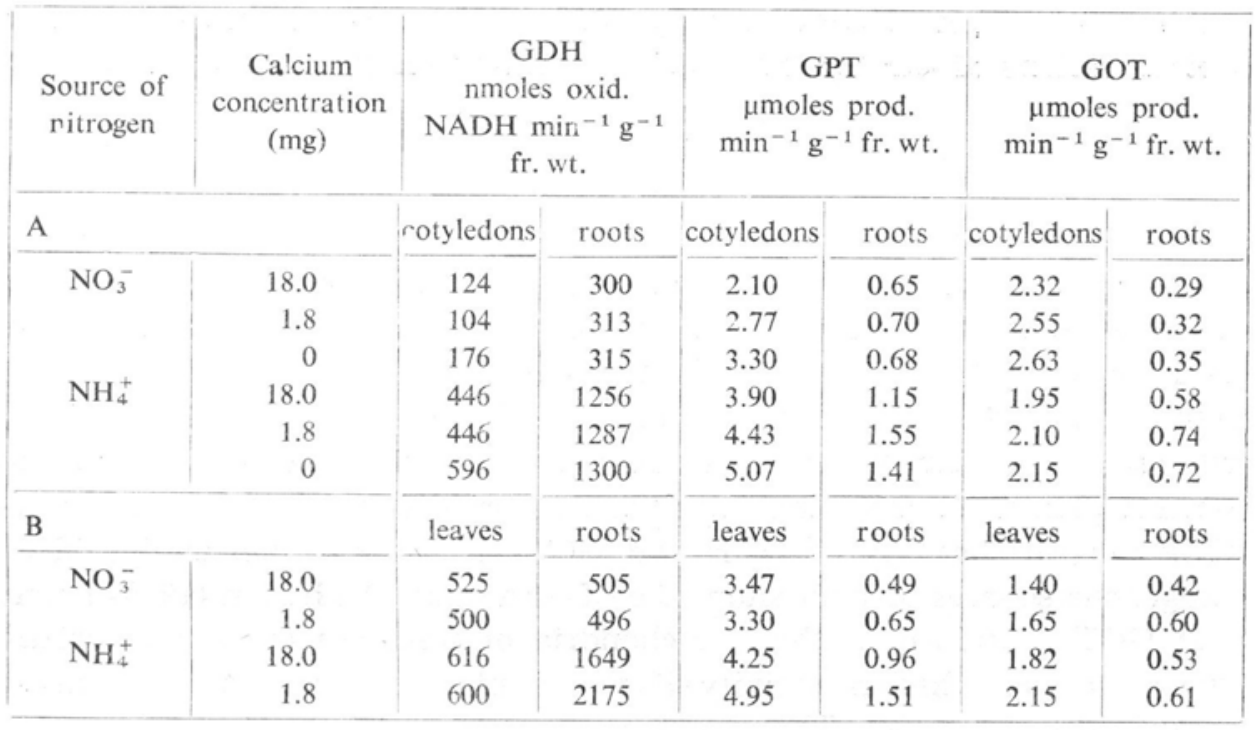

a medium lacking nitrogen and potassium $(-\mathrm{N},-\mathrm{K})$, and in a medium lacking nitrogen and calcium (-N, -Ca). After four days of growth of seedlings in the mentioned types of media, a very distinct increase in GDH activity was observed as a result of the lack of $\mathrm{K}^{+}$or $\mathrm{Ca}^{2+}(\mathrm{Ta}-$ ble 5). Lack of $\mathrm{K}^{+}$led to a two-fold increase in GDH activity in the roots, and lack of $\mathrm{Ca}^{2+}$ to a four-fold increase of GDH activity in these organs. GDH activity in cotyledons increased to 140 and $350 \%$, respectively. Data collected in Table 5 furthermore show that lack of potassium or calcium ions in a medium which at the same time does not contain nitrogen, resulted in an increase of GOT and GPT activity. In this case roots reacted more distinctly with respect to increased activity of these aminotransferases.

Table 5

GDH, GPT, and GOT activity after 4 days of growth of cucumbers in a medium lacking nitrogen and potassium $(-\mathrm{N},-\mathrm{K})$ or nitrogen and calcium $(-\mathrm{N},-\mathrm{Ca})$ in relative values in relation to a control medium (lacking nitrogen, $-\mathrm{N}$ )

\begin{tabular}{|c|c|c|c|c|c|c|}
\hline $\begin{array}{c}\text { Nutrient } \\
\text { medium }\end{array}$ & \multicolumn{2}{|c|}{ GDH } & \multicolumn{2}{c|}{ GPT } & \multicolumn{2}{c|}{ GOT } \\
\hline cotyledons & roots & cotyledons & roots & cotyledons & roots \\
\hline$-\mathrm{N}$ & 100 & 100 & 100 & 100 & 100 & 100 \\
$-\mathrm{N},-\mathrm{K}$ & 140 & 226 & 150 & 225 & 139 & 133 \\
$-\mathrm{N},-\mathrm{Ca}$ & 350 & 400 & 118 & 159 & 117 & 126 \\
\hline
\end{tabular}


Investigations in vitro carried out on crude extracts did not show any direct influence of $\mathrm{K}^{+}$ions on GDH, GPT and GOT activity or any direct influence of $\mathrm{Ca}^{2+}$ ions on $\mathrm{GDH}$ and GOT activity. Only a slight inhibition of GPT activity was noted in the presence of higher concentrations of $\mathrm{Ca}^{2+}$ (around $30 \%$ of inhibition at $20 \mathrm{mM} \mathrm{Ca}^{2+}$ ).

\section{DISCUSSION}

As a result of investigations it was found that supplying cucumber seedlings with $\mathrm{K}^{+}$and $\mathrm{Ca}^{2+}$ ions fashions the level of GDH, GPT and GOT activity. Harper and Pa ulsen (1969) observed higher GDH activity in the leaves of wheat growing in the absence of $\mathrm{Ca}^{2+}$ ions, whereas GOT activity in leaves remained at the same level as in the control plants. At the same time the authors did not find any differentiation in the activity of GDH and GOT in leaves of wheat devoid of exogenous sources of potassium. B e s f o r d and $\mathrm{H}$ o b s o n (1975) found that GOT contained in the mitochondria of tomatoes are characterized by considerably higher activity if the plants developed at a decreased availability of $\mathrm{K}^{+}$ions. These results were also confirmed by $\mathrm{Ach} \mathrm{it} \mathrm{u} \mathrm{v}$ and $\mathrm{Bar}-\mathrm{Akiva}$ (1976) by finding increased GOT activity in the leaves of citrus plants developing in the absence of $\mathrm{K}^{+}$. Although in the present investigations lowered $\mathrm{K}^{+}$and $\mathrm{Ca}^{2+}$ concentrations in media were linked with an increase in GDH, GPT and GOT activity, results obtained were affected by the amount of $\mathrm{K}^{+}$and $\mathrm{Ca}^{2+}$ used, the form of mineral nitrogen assimilated by the cucumbers as also by the plant organ in question.

As shown by investigations carried out by $\mathrm{Pahlich}$ and $\mathrm{Joy}$ (1971), Ehmke and Hartmann (1976) application of EDTA or dialysis led to intensive lowering of GDH activity followed by its restoration after adding $\mathrm{Ca}^{2+}$ ions. These data indicate that indispensability of bivalent cations for maintaining GDH activity results from stabilization of enzymatic protein conformation by these cations. However, cucumber tissues contain a certain pool of $\mathrm{Ca}^{2+}$ ions originating, among others, from reserve material in their cotyledons (Table 2). As shown by studies carried out by $\mathrm{Pahlich}$ and $\mathrm{H}$ of mann (1975), as likewise by the present studies, introduction of $\mathrm{Ca}^{2+}$ ions into the incubations mixture containing intact enzyme does not change its activity. As shown by investigations conducted in vivo, increase of GDH activity in the tissues of cucumbers resulting from the absence of $\mathrm{Ca}^{2+}$ ions in the medium is especially distinct after eliminating nitrogen from the composition of the medium (Table 5). It appears probable that the observed growth of GDH activity does not result directly from the reaction of $\mathrm{Ca}^{2+}$ ions on the enzyme, but constitutes the results of the disruptions 
taking place in other processes only indirectly connected with the functioning of GDH.

Davies and Ellis (1961), Wightman and Forest (1978) indicate that in vitro $\mathrm{Ca}^{+2}$ ions stimulate aspartate aminotransferase. However, in the present studies carried out on cucumber extracts addition of $\mathrm{K}^{+}$or $\mathrm{Ca}^{2+}$ to the incubation mixture did not affect any change in the activity of the aminotransferase investigated. Cooper and $\mathrm{H}$ ill- Cotting h a (1974) similarly showed that in vitro $\mathrm{Ca}^{2+}$ ions did not change GOT activity extracted from the tissues of apple trees. It appears rather probable that the observed increase in GPT and GOT activity resulted with the lack of $\mathrm{K}^{+}$or $\mathrm{Ca}^{2+}$ in the medium does not result from the direct reaction of these ions on the aminotransferases under investigation. As given by $\mathrm{Kurs}$ a nov et al. (1965) increase of the intensiveness of respiration can be initially observed at a deficiency of potassium. It is probable that the rate of respiratory processes constituting the source of ketoacids in glutamate biosynthesis as likewise during transamination might affect the level of activity of the enzymes under investigation.

After determining the nitrogen forms contained in the various organs of plants developing at lower doses of $\mathrm{K}^{+}$or $\mathrm{Ca}^{2+}$, or in the absence of these ions, increased accumulation of total and nonprotein nitrogen was noted in many of the combinations. Ste in berg (1956) similarly observed an increase in soluble nitrogen in tobacco leaves in connection with the lack of $\mathrm{K}^{+}$or $\mathrm{Ca}^{2+}$ in the medium. Investigations carried out on cucumber seedlings did not show any precise correlation between the content of non-protein nitrogen and activity of the enzymes investigated, this probably being due to the relatively low share played by amino acids constituting the end product in the total pool of nonprotein nitrogen amassed in the plant and catalyzed by GDH, GPT and GOT. The results obtained do, however, allow for the assumption that amassing larger amounts of free amino acids by plants showing symptoms of calcium or potassium deficiency ( $\mathrm{T}$ s e and M c M u r tre y 1960, Vysk re bentse va 1963) is linked with increased GDH, GPT and GOT activity.

\section{Acknowledgments}

This study was financed from Problem MR II/7.

\section{REFERENCES}

Achituv M., Bar-Akiva A., 1976. Glutamic-oxaloacetic transaminase in leaves of phosphorus-deficient citrus plants. Physiol. Plant. 36: 368-373.

Besford R. T., Hobson G. E., 1975. Effect of potassium nutrition on some enzymes from ripening Lycopersicon esculentum fruit. Phytochemistry 14: 57-59. 
Brzeski W., Kaniuga Z., 1956. Cwiczenia z biochemii roślin. PWN Warszawa, pp. 89-104.

Buczek J., 1979. Ammonium and potassium effect on nitrate assimilation in cucumber seedlings. Acta Soc. Bot. Pol. 48: 157-169.

Cooper D. R., Hill-Cottingham D. G., 1974. Glutamic dehydrogenase and glutamic-oxalacetic transaminase in apple tree tissues. Physiol. Plant. 31: 193-199.

Davies D. D., Ellis R. J., 1961. Glutamic-oxaloacetic transaminase of cauliflower. 2. Kinetics and mechanism of action. Biochem. J. 78: 623-630.

Ehmke A., Hartmann T., 1976. Properties of glutamate dehydrogenase from Lemna minor. Phytochemistry 15: 1611-1617.

Evans H. J., Sorger G. J., 1966. Role of mineral elements with emphasis on the univalent cations. Ann. Rev. Plant Physiol. 17: 47-76.

Fialova S., Pichl I., 1973. Plant nitrogen metabolism and calcium or potassium deficiency. Biol. Plant. 15: 194-201.

Harper J. E., Pa u 1 s en G. M., 1969. Nitrogen assimilation and protein synthesis in wheat seedlings as affected by mineral nutrition. I. Macronutrients. Plant Physiol. 44: 69-74.

Hedley C. L., Stoddart J. L., 1971. Light stimulation of alanine aminotransferase activity in dark grown leaves of Lolium temulentum L. as related to chlorophyll formation. Planta 100: 309-324.

Kubik-Dobosz G., Soroka K., 1979. Influence of light and mineral nitrogen forms on the activity of some enzymes in Cucumis sativus L. cotyledons. Acta Soc. Bot. Pol. 48: 443-452.

Kursanov A., Vyskrebentseva E., Svesnikova I., Krasavina M., 1965. Dezorganizaciya energeticeskogo obmena w kornyakh pri kaliinom golodanii. Dokl. Akad. N. SSSR 162: 211-214.

Mejbaum-Katzenellenbogen W., Mochnacka I., 1969. Kurs praktyczny z biochemii. PWN Warszawa, pp. 166-179.

Mengel K., Simic R, 1973. Effect of potassium supply on the acropetal transport of water, inorganic ions and amino acids in young decapited sunflower plants (Helianthus annuus). Physiol. Plant. 28: 232-236.

Pahlich E., Hoffman J., 1975. Utber den Reactionsmechanismus pflanzlicher Glutamatdehydrogenase und die Regulation der Aktivität durch Adenosinphosphate, die Energieladung und Ionen. Planta 122: 185-201.

Pahlich E., J oy K. W., 1971. Glutamate dehydrogenase from pea roots. Purification and properties of the enzyme. Can. J. Biochem. 49: 127-138.

Pa 1 R. N., La 1 or a y M. M., 1973. Calcium in relation to nitrogen metabolism. II. Changes in free amino acids and amides in peanut plants. Biochem. Physiol. Pflanzen 164: 547-565.

P a u 1s en G. M., H a r per J. E., 1968. Evidence for a role of calcium in nitrate assimilation in wheat seedlings. Plant Physiol. 43: 775-780.

Steinberg R. A., 1956. Metabolism of inorganic nitrogen by plants. In: Inorganic nitrogen metabolism. Eds. McElroy W. D. and Glass B., John Hopkins, Maryland, pp. 153-158.

Ts o T. C., Mc Murtrey J. E. Jr., 1960. Mineral deficiency and organic constituens in tabacco plants. II. Amino acids. Plant Physiol. 35: 865-870.

Vyskrebentseva E. I., 1963. Okislitelnyi i azotistyi obmen w kornyakh tykvy pri kaliinom golodanii. Fizjol. Rast. 10: 307-312.

Wightman F., Forest J. C., 1978. Properties of plant aminotransferases. Phytochemistry 17: 1455-1471. 
Wpływ jonów potasowych $i$ wapniowych na metabolizm azotowy siewek ogórka

\section{Streszczenie}

Badano zawartość frakcji azotu, potasu i wapnia oraz aktywność dehydrogenazy glutaminianowej $(\mathrm{GDH})$, aminotransferazy alaninowej (GPT) i aminotransferazy asparaginianowej (GOT) w siewkach ogórka rosnących 4 lub 13 dni w pożywce azotanowej bądź amonowej o zróżnicowanej zawartości jonów $\mathrm{K}^{+}$względnie $\mathrm{Ca}^{2+}$. Zmniejszenie zawartości $\mathrm{K}^{+} \mathrm{w}$ pożywce amonowej doprowadziło do wzrostu ilości zakumulowanego azotu całkowitego i niebiałkowego. Niewielka dawka $\mathrm{Ca}^{2+}$ lub całkowity brak tego składnika w pożywkach wiązal się ze znacznym spadkiem zawartości potasu w tkankach roślin, a także ze zwiększeniem w niektórych organach ogórków frakcji azotu niebiałkowego. W liścieniach i korzeniach ogórków pozbawionych egzogennego źródła azotu oraz potasu lub wapnia obserwowano wyraźny wzrost aktywności GDH, GPT i GOT. Podobne podwyższenie aktywności badanych enzymów zaznaczyło się w różnych organach siewek rosnących w pożywce azotanowej lub amonowej o zmniejszonej zawartości $\mathrm{K}^{+}$lub $\mathrm{Ca}^{2+}$. Uzyskane rezultaty wskazują na wpływ jonów $\mathrm{K}^{+}$i $\mathrm{Ca}^{2+}$ na poziom aktywności GDH, GPT i GOT, jednakże wielkość zmian zależy od zastosowanej dawki tych jonów, formy azotu mineralnego pobieranego przez rośliny, fazy rozwoju oraz rozpatrywanego organu roślin. 